\title{
AS FEIÚRAS FÍSICA E MORAL FEMININAS EM CANTIGAS DE ESCÁRNIO E MALDIZER DE AFONSO $\mathrm{X}$
}

\author{
Vanessa Giuliani Barbosa Tavares ${ }^{1}$
}

RESUMO: Estuda a descrição feminina em três cantigas de escárnio e maldizer do rei e trovador medieval Afonso X, fundamentado em estudos interdisciplinares: crítico-literários, filológicos e histórico-culturais. Partindo de uma investigação histórica sobre a misoginia medieval, analisa nas cantigas as descrições que escarnecem as mulheres por sua feiura física ou moral. Identifica que a literatura satírica afonsina, embora lúdica, configura-se como um discurso misógino, o qual, ao zombar a aparência ou a conduta das mulheres satirizadas, atuava como um instrumento de denúncia e de regulação da conduta feminina na sociedade medieval peninsular.

PALAVRAS-CHAVE: Cantigas satíricas galego-portuguesas; Afonso X - séc. XIII; Mulher medieval; Feiura feminina.

\section{THE FEMININE PHYSICAL AND MORAL UGLINESS IN ALFONSO X'S CANTIGAS DE ESCÁRNIO E MALDIZER}

\begin{abstract}
It studies the description of women in three Alfonso X's cantigas de escámio e maldizer, based on interdisciplinary studies: critical-literary, philological and historical-cultural. Starting from a historical investigation about the medieval misogyny, it analyzes in the cantigas the descriptions that mock the women because of their physical or moral ugliness. It identifies in Alfonso X's satirical literature, although playful, is configured as a misogynist discourse, which, by mocking the appearance or behavior of satirized women, acted as instrument of denunciation and regulation of female conduct in peninsular medieval society.
\end{abstract}

KEYWORDS: Galician-Portuguese satirical songs; Alfonso X - century XIII; Medieval woman; Feminine ugliness.

\section{Considerações iniciais}

As cantigas de escárnio e maldizer galego-portuguesas, um dos três gêneros principais da tradição trovadoresca peninsular do século XII ao XIV, eram, de acordo com o tratado anônimo fragmentário Arte de trovar, "aquelas que os trovadores fazem querendo dizer mal de alguém nelas" (A POÉTICA, 2005, p. 2). O espólio de cantigas satíricas deixadas pelo trovadorismo galego-português é significativo: Graça Videira Lopes (1998) contabiliza que "das 1.679 cantigas profanas que chegaram até nós, cerca de 465 sejam satíricas, produzidas por cerca de 93 trovadores e jograis” (LOPES, 1998, p. 30). Tais

\footnotetext{
${ }^{1}$ Mestranda do Programa de Pós-Graduação em Letras da Universidade Federal do Espírito Santo. Bolsista Capes.
} 
composições satirizavam personagens específicos da corte ou grupos sociais e profissionais, abordando, de forma cômica, o vulgar, o obsceno e o ridículo, apoiadas em uma "função lúdica” (MONTOYA-MARTINEZ, 1989, p. 437). Contudo, para além deste objetivo, esses poemas eram acompanhados de um discurso com propósito reformador, que intervinha no desvio ou rompimento de valores estéticos ou morais, de modo a repreender o que era considerado desajustado à sociedade do ocidente medieval.

Um dos trovadores de destaque do período foi Afonso X, rei de Castela e Leão (1252-1284), cognominado "O Sábio", e "considerado autor de algumas das cantigas satíricas mais grosseiras e obscenas produzidas em seu reinado" (PAREDES, 2010, p. 36). A corte afonsina foi palco e ponto de encontro fundamental entre poetas da produção trovadoresca do século XIII, período considerado o mais fértil na produção das cantigas galego-portuguesas, patrocinadas e também compostas pelo rei. Pela edição crítica do cancioneiro profano afonsino, de Juan Paredes, contata-se que o rei-trovador deixou uma produção poética vasta: "o conjunto de 427 cantigas religiosas, as Cantigas de Santa Maria, e também 44 cantigas profanas, das quais 39 são de escárnio e maldizer" (PAREDES, 2010, p. 35).

Dentre os diversos grupos satirizados por Afonso X - e por seus companheiros trovadores - várias cantigas tinham como alvo as mulheres. Lopes (1998) contabiliza que "cerca de 106, das 465 cantigas satíricas que até nós chegaram, são dirigidas a mulheres" (LOPES, 1998, p. 227). Depreende-se, desse modo, que "a muller se configura como centro indiscutible da cultura trobadoresca" (CORRAL-DIAZ, 1996, p. 16), posto que aparecem como protagonistas nos dois gêneros líricos principais - cantigas de amor e de amigo, e também são com frequência personagens no gênero satírico - escárnio e maldizer.

No Dicionário da literatura medieval galega e portuguesa, Giulia Lanciani (1993) explica que, em resumo, nas cantigas de amor e amigo cantava-se o tema do amor não correspondido ou impedido. As mulheres louvadas nas cantigas de amor eram as damas refinadas e inacessíveis e nos cantares de amigo, por sua vez, eram as "donzelas simples, ingênuas e vulneráveis" (LANCIANI, 1993, p. 135-138). Baseada, pois, no amor cortês, que impunha um modelo de total submissão masculina à dama, essa literatura sublimava a mulher, tornando-a exemplo de perfeição estética e moral, dado que nas protagonistas estavam reunidas todas as virtudes humanas. 


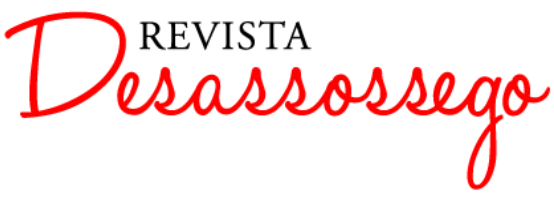

DESASSOSSEGO 17 | JUN/2017 | ISSN 2175-3180

DOI: http://dx.doi.org/10.11606/issn.2175-3180.v9i17p128-143

Contudo, apesar da impressão de exaltação feminina, não é a mulher, mas sim o homem que ocupa o primeiro plano:

todos esses escritos [canções e romances corteses provençais e franceses] foram feitos para entretenimento do homem. Eu clarifico: dos homens de guerra, dos cavaleiros. Mais precisamente ainda para os "jovens". São jovens e cavaleiros todas as personagens heroicas cujas proezas os autores de romances celebram, e as figuras femininas que os rodeiam não estão lá senão para valorizar mais esses homens, para realçar as suas qualidades viris. Jovens e cavaleiros são-no também todos os que dizem "eu" nas canções, e se por vezes o discurso é apresentado como o de uma mulher, tudo leva a crer que no século XII, na maioria dos casos, ele tinha sido elaborado por um homem que, para agradar àqueles que $o$ ouviam, se aplicou em exprimir sentimentos e atitudes que se costumavam atribuir aos parceiros de outro sexo. Estes poemas não mostram a mulher. Mostram a imagem que os homens faziam dela (DUBY, 1993, p. 336).

Dessa maneira, vê-se que esses textos eram caracterizados por um enobrecimento masculino que conservava a ordem social daquele contexto no qual a misoginia era amplamente difundida. Por meio do jogo cortês, o homem era responsável por conduzir o cortejo, e a mulher, por controlar seus desejos e impulsos:

com efeito, o jogo de amor não pretendia de forma alguma perturbar as relações hierárquicas que subordinavam o feminino ao masculino no seio do sistema de relações sociais, cuja armadura ele contribuía para fortificar. Desde que chegasse ao fim, desde que se voltasse à seriedade da vida, a 'amiga' voltava à condição onde Deus tinha colocado a sua espécie, o seu gênero, recaía sobre o estreito controlo do homem de quem, como esposa, filha ou irmã, dependia (DUBY, 1993, p. 346).

$\mathrm{Na}$ sátira, distanciada das descrições idealizadas e inverossímeis das cantigas de amor e amigo, a caracterização feminina colocava em evidência uma visão insultuosa. Diferente dos gêneros amorosos, o escárnio e maldizer não cantava a dama refinada ou a donzela ingênua, e sim as "soldadeiras, prostitutas, mulheres do povo, velhas feias e 'fududancuas', objetos de uso e de desprezo" (VIEIRA, 1983, p. 106). Dessa forma, os insultos eram construídos por meio de descrições obscenas, relacionadas, sobretudo, às práticas sexuais e aos defeitos físicos dessas mulheres. Por este motivo, a caracterização e o tratamento dados às mulheres na sátira galego-portuguesa evidenciam uma visão misógina e menosprezadora, uma vez que essa poesia exibe registros eróticos e grotescos que ridicularizam a figura feminina e suas características estéticas e comportamentais tidas como inadequadas para a sociedade peninsular. 


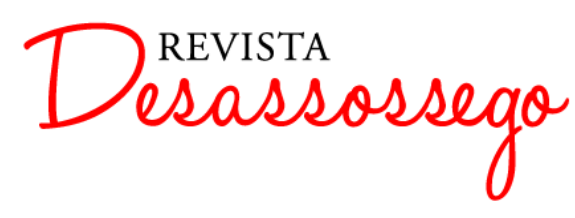

DESASSOSSEGO 17 | JUN/2017 | ISSN 2175-3180

DOI: http://dx.doi.org/10.11606/issn.2175-3180.v9i17p128-143

Desse modo, serão investigadas três cantigas de Afonso X - "Joan Rodriguiz foi esmar a Balteira" (B 481, V 64), "Non quer eu donzela fea" (B 476) e "Achei Sancha Anes encavalgada" (B 458) - com o objetivo de analisar as descrições femininas e sua relação com o que era considerado feio ou imoral no período medievo, de modo a observar como tais registros literários corroboravam a misoginia.

\section{A misoginia medieval, a feiura feminina e o riso satírico}

Dado que o contexto histórico no qual se localizam os textos literários são sempre um suporte viável para a análise literária, faz-se relevante uma compreensão sobre as condições sociais femininas na baixa Idade Média europeia. Nesse período, as mulheres não eram dotadas de grandes direitos e privilégios e estavam sempre sob a tutela de um homem, seja o pai, o irmão, o marido ou os líderes religiosos. A organização social contribuía para essa sujeição:

em efecto, as mulleres formabam evidentemente parte da sociedade
medieval, constituída com uma estructura de clases xerarquizada e
estreitamente ordenada. As leis que rexían a devandita sociedade eran
elaboradas e aplicadas por homes que - salvo excepcíons - consideraban
a muller baixo os pressupostos da indiscutida superioridade do home
sobre a muller (CORRAL-DIAZ, 1996, p. 12).

Desse modo, entre os séculos XII e XIV, a condição feminina era, em geral, de subordinação ao homem, defendida pelas "supostas deficiências da natureza feminina, como a fragilidade do corpo e a incapacidade militar" (TUDELA Y VELASCO, 1983, p. 60), além da visão cristã que aponta a mulher como um ser inferior ao homem, por ser criada a partir uma costela masculina e causador da queda da humanidade, tornando-se maculado pelo pecado. Nesse sentido, o Cristianismo, como força dominante na Idade Média, agia como um dos principais - se não o principal - meios repressores e condenatórios à mulher, e isso se deve ao histórico pecaminoso ao qual ela sempre esteve vinculada. Conforme Chiara Frugoni, a mulher, no livro bíblico do Gênesis, é a responsável pela condenação da humanidade ao deixar-se seduzir pelo Diabo e impelir o companheiro à desobediência. Com isso, a condenação de Eva pelo ato pecaminoso foi a dominação do homem sobre a mulher, além da multiplicação do sofrimento para todas o gênero feminino (FRUGONI, 1993, p. 461-462).

Nesse contexto, inúmeros tratados teológicos e filosóficos expressavam a misoginia e normatizavam o comportamento das mulheres. Dentre eles, identifica-se como exemplo 
significativo o Tratado do amor cortês (2000), de André Capelão, escrito por volta do ano 1200 e dividido em três livros ou partes. Nos dois primeiros, é apresentada uma doutrina sobre o amor, julgando-o como fonte de todo o bem. No terceiro livro, em contradição aos ensinamentos relacionados ao amor cortês, o Capelão acusa o amor de ser a causa de todos os males, de todos os vícios e crimes humanos e aponta a mulher como responsável por eles, construindo um quadro acusador e opressor, no qual todas a mulheres, sem exceção, seriam constituídas apenas defeitos e formadas por uma natureza maligna:

as mulheres, aliás, não são apenas avaras por natureza, mas também são curiosas e falam mal das outras mulheres; são vorazes, escravas do próprio ventre, volúveis, inconstantes, desobedientes, rebeldes às proibições; são maculadas pelo pecado do orgulho e cobiçam a vanglória; são mentirosas, dissolutas, tagarelas, não respeitam segredos; são luxuriosas ao extremo, dadas a todos os vícios e não tem afeição verdadeira pelo homem (CAPELÃO, 2000, p. 290).

Ligada a essa suposta natureza pecaminosa feminina, havia uma preocupação com a aparência e o comportamento delas, "visando à constituição de um rígido e prescritivo protocolo moral e religioso acerca do seu modo de vestir, adornar e maquiar" (FONSECA, 2014, p. 442). Pedro Fonseca aponta, na literatura clássica de Tertuliano, o estabelecimento de padrões comportamentais e estéticos a serem seguidos pelas mulheres, de modo que possam se redimir pelo mal que as acompanha:

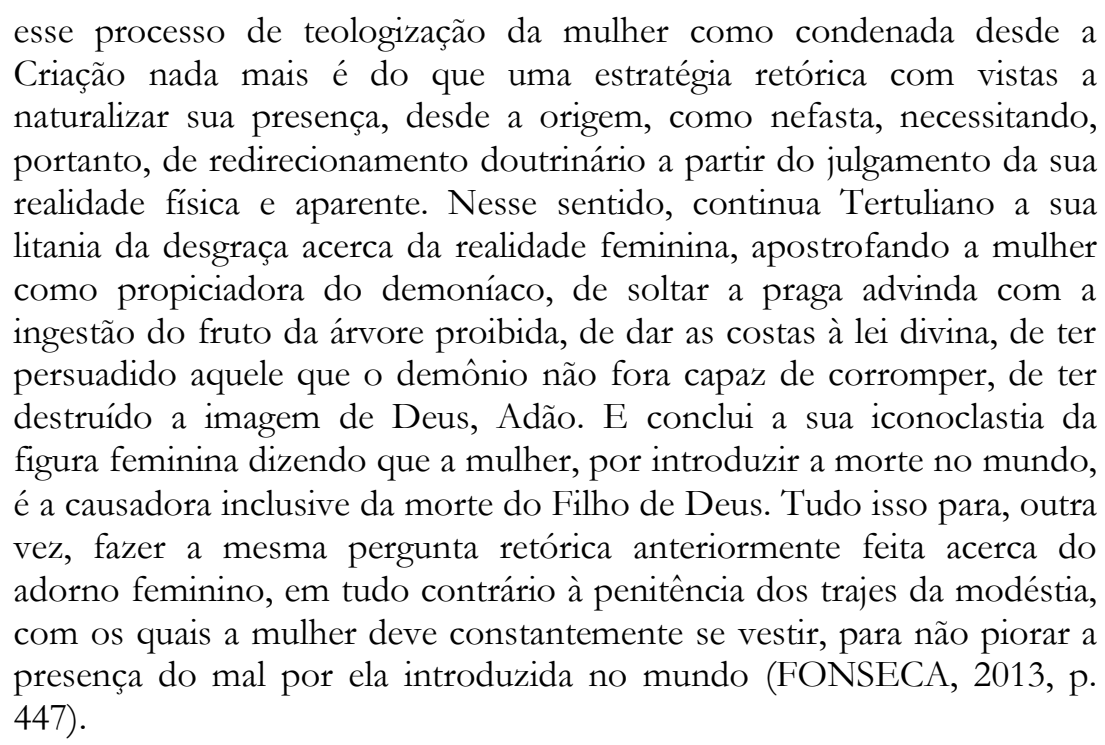

Outrossim, a prescrição de modelos que objetivavam a padronização da aparência feminina estava relacionada à custódia do gênero durante a Idade Média. De acordo com Carla Casagrande (1993), a participação social da mulher sempre esteve condicionada a uma 
separação entre o interior - espaço privado e interno das casas, alma - e o exterior - espaço público e externo das comunidades, corpo -, sendo que aquele deveria sempre ser priorizado em detrimento deste. A partir disso, a mulher era afastada da vida pública e relegada ao espaço de sua casa, além de limitada à interioridade de sua alma (CASAGRANDE, 1993, p. 125). Dessa forma, a estética não deveria ser privilegiada, sob o risco de uma valorização demasiada do exterior:

a mulher maquilhada e vestida com sumptuosidade privilegia, contrariamente à ordem querida por Deus, a vil exteriorização do seu corpo em relação a preciosa interioridade da sua alma: o excessivo agrado que mostra por uma roupa que lhe envolve o corpo, pela cor de um tecido que a valoriza ou por um penteado que lhe fica bem, trai um interesse todo voltado para o cuidado exterior do corpo, que não deixa espaço nem tempo para o cuidado amoroso da virtude. A cosmética em especial, revela uma soberba sem limites: a mulher que pinta as suas faces de vermelho ou que altera a cor dos cabelos ou que esconde os sinais de envelhecimento sob cosméticos e perucas é uma mulher que, a par de Lúcifer, contesta e pretende melhorar a imagem que Deus the deu, chegando até a julgar-se capaz de intervir nas leis da temporalidade governadas por Ele (CASAGRANDE, 1993, p. 126)

Ainda, visto que exercia tal controle sobre a sociedade e principalmente sobre as mulheres, a Igreja era responsável também por controlar o sexo e a sexualidade. Tal censura devia-se à sua inclinação de desviar o indivíduo de sua busca pela perfeição espiritual; e as mulheres, nesse caso, agiriam como protagonistas desse desvio nas relações heterossexuais, já que eram consideradas contaminadas pelo pecado e luxuriosas, na medida em que "nenhuma delas, mesmo que de ilustríssima posição, rejeitaria um homem que seja competente em amor" (CAPELÃO, 2000, p. 301). Sendo assim, a castidade, em detrimento dos prazeres sexuais, foi sempre recomendada às mulheres, levando em consideração que eram responsáveis pela "concupiscência à qual a humanidade inteira foi condenada depois do pecado original" (CASAGRANDE, 1993, p. 110).

O modelo feminino de beleza e temperança torna-se ainda mais influente a partir do século XII, principalmente pela intensificação do culto mariano. Conforme Jacques Dalarun, Maria, inacessível e sublime, opõe-se a Eva, humana e pecadora, visto que aquela, que segundo a narrativa bíblica concebeu o filho de Deus de forma pura e sem nenhum contato sexual, simbolizava a castidade e a simplicidade a serem alcançadas pelo gênero feminino. Com isso, "para impedir que as mulheres desesperem de alcançar a sorte dos bem-aventurados, já que uma mulher esteve na origem de um mal tão grande, é preciso, para lhe restituir a esperança, que uma mulher esteja na origem de um bem igualmente 
grande” (DALARUN, 1993, p. 39). Sob esse viés, Maria foi projetada como figura modelar para as mulheres, simbolizando o paradigma inalcançável dos valores que elas deveriam almejar. Funda-se, pois, uma antinomia: Eva-Maria; uma simbolizando mais as mulheres reais e a outra, a mulher ideal, porém inalcançável (DALARUN, 1993, p. 53).

Logo, verifica-se que não somente a estética feminina, mas também o comportamento sexual era refreado e normalizado pelas forças políticas e sociais dominantes na Idade Média. Em síntese, pode-se inferir que a esse propósito normativo serviram também as cantigas satíricas galego-portuguesas: ao satirizar as mulheres de conduta moral e aparência física indesejada, tal literatura denunciava sua inadequação aos padrões sociais e religiosos medievais, por meio da descrição de particularidades concernentes à sua feiura, seja ela física ou moral.

Quanto à feiura, reconhece-se que ela se manifesta de maneira distinta nas sociedades. Os estudos de Umberto Eco, História da beleza (2004) e História da feiura (2007) esclarecem que "muitas vezes, as atribuições de beleza ou de feiura eram devidas não a critérios estéticos, mas a critérios políticos e sociais" (ECO, 2007, p.12). Nesse sentido, as peculiaridades do que é ou não considerado feio em um contexto social específico são referentes a aspectos tanto estéticos quanto éticos. Também, reconhece-se que os sinônimos de feio são sempre motivadores de um sentimento de repulsa, enquanto as definições de belo causam uma reação de admiração:

se examinarmos os sinônimos de belo e feio, veremos que, enquanto se considera belo aquilo que é bonito, gracioso, prazenteiro, atraente, agradável, garboso, delicioso, fascinante, harmônico, maravilhoso, delicado, leve, encantador, magnífico, estupendo, excelso, excepcional, fabuloso, legendário, fantástico, mágico, admirável, apreciável, espetacular, esplêndido, sublime, soberbo; é feio aquilo que é repelente, horrendo, asqueroso, desagradável, grotesco, abominável, vomitante, odioso, indecente, imundo, sujo, obsceno, repugnante, assustador, abjeto, monstruoso, horrível, hórrido, horripilante, nojento, terrível, terrificante, tremendo, monstruoso, revoltante, repulsivo, desgostante, aflitivo, nauseabundo, fétido, apavorante, ignóbil, desgracioso, desprezível, pesado, indecente, deformado, disforme, desfigurado (ECO, 2007, p. 16)

Diante disso, percebe-se a ideia de que o belo esteve sempre associado ao bom e ao sublime, e o feio é análogo ao mal e ao pecado e, por isso, em um contexto marcado pelo Cristianismo, como a Idade Média ocidental, o belo e o bom são relacionados ao céu e às virtudes, e o feio e mal, ao inferno e ao pecado (ECO, 2004, p. 164). No Ocidente 
medieval, por exemplo, o ideal literário de beleza da mulher era de um objeto de amor casto e sublime, desejada mas inatingível, motivado pelos princípios do amor cortês, e as mulheres que se afastavam desses valores eram tidas como feias.

Todavia, a feiura e a imoralidade, apesar da gravidade de sua manifestação, eram representadas de forma humorada nas cantigas satíricas galego-portuguesas. De acordo com Eco, comicidade e obscenidade relacionam-se à medida que rimos daquilo que desprezamos:

nas culturas em que existe um forte senso de pudor, o gosto por sua violação manifesta-se através do oposto do pudor, que é a obscenidade. Pode-se exibir comportamentos obscenos por raiva ou por provocação, mas com muita frequência a linguagem ou o comportamento obsceno simplesmente fazem rir (ECO, 2007, p. 131).

Conforme Vladimir Propp, o riso ocorre em presença de duas grandezas: de um objeto ridículo e de um sujeito que ri:

\begin{abstract}
é possível rir do homem em quase todas as suas manifestações. [...] podem ser ridículos o aspecto da pessoa, seu rosto, sua silhueta, seus movimentos. Podem ser cômicos o raciocínio em que a pessoa aparenta pouco senso comum; um campo especial de escárnio é constituído pelo caráter do homem, pelo âmbito da vida moral, de suas aspirações, de seus desejos e de seus objetivos. Pode ser ridículo o que o homem diz, como manifestação daquelas características que não eram notadas enquanto ele permanecia calado. Em poucas palavras, tanto a vida física quanto a vida moral e intelectual do homem podem tornar-se objeto de riso. (PROPP, 1992, p. 29)
\end{abstract}

Ainda no tocante ao riso, em "O riso na Idade Média", Jacques Le Goff aponta três teorias, propostas por John Morreall, e comenta como se dá nelas a relação entre o feio, o obsceno e o risível:

a teoria da superioridade, segundo a qual a pessoa que ri essencialmente tenta dominar um interlocutor ou alguém que o encara por causa do seu riso. A segunda é a teoria da incongruência: o riso se origina, basicamente, na percepção de algo fora dos padrões normais da natureza ou da sociedade; essa é a teoria proposta por Bergson, elaborada a partir de sua idéia da percepção de uma ação mecânica na qual devia ter havido algo espontâneo. E, finalmente, há a teoria do alívio, segundo a qual as pessoas que riem liberam um comportamento que, de outro modo, teria expressão e consequências muito mais difíceis (LE GOFF, p. 75).

Além disso, Le Goff analisa a figura do rex facetus medieval, a partir da qual percebese até que:

o riso estava quase se tornando um instrumento de governo ou, de qualquer modo, uma imagem de poder. [...] nas mãos do rei, o riso era 
um meio de estruturar a sociedade ao seu redor. Ele não troçava de todos indiscriminadamente ou da mesma maneira. A obscenidade também era um dos 'deslizes' do riso (LE GOFF, 2000, p. 71).

Apesar disso, sabe-se que nem toda característica ou costume humano são cômicos. O belo e o harmonioso não podem despertar o riso, o que o desperta são os defeitos internos e externos, principalmente aqueles indesejados em determinados contextos sociais e culturais. No caso das cantigas de escárnio e maldizer galego-portuguesas, risíveis eram os defeitos físicos ou os comportamentos que distanciavam o sujeito do que era considerado adequado, o que pode confirmar a função de intervenção social atribuída a essa literatura.

Dessa forma, tais hipóteses podem ser associadas ao duplo propósito - lúdico e moral - que acompanha as cantigas satíricas galego-portuguesas. No caso das que descrevem as mulheres, a teoria da superioridade seria descrita pelo caráter moralizante das cantigas: ao fazerem humor com as características delas, os trovadores se mostram superiores, seja pela relação masculino-feminino ou pela diferenciação moral-imoral. Já a teoria da incongruência alia-se à feiura estética e moral dessas mulheres: o defeito físico ou comportamental descrito nas cantigas seria responsável por afastá-las dos padrões sociais estabelecidos na Idade Média peninsular e, por isso, seriam elas motivo de riso. Por fim, a teoria do alívio expõe a dualidade entre o riso e a condenação notada nas cantigas: o humor realiza-se a partir da imagem das fraquezas e dos vícios humanos que devem ser reprimidos, e uma forma de repressão é a ridicularização. Por fim, pode-se perceber que figura do rex facetus medieval se ajustava à de Afonso $\mathrm{X}$ que, como rei e trovador satírico, atuava como um rei faceto.

Logo, as cantigas de escárnio e maldizer compostas por Afonso X podem ser interpretadas como uma representação dos comportamentos femininos considerados inadequados, ao mesmo tempo em que, na imagem de autoridade do rei, são tidas como prescrições de boa aparência e conduta a serem seguidas.

\section{Três cantigas satíricas de Afonso $\mathrm{X}$ dirigidas às mulheres feias e/ou imorais}

Utilizando como base a edição crítica de Juan Paredes, El cancionero profano de Alfonso X El Sabio (PAREDES, 2010), cotejada com a edição crítica de Rodrigues Lapa (LAPA, 1995) e a base de dados das cantigas profanas galego-portuguesas de Graça Videira Lopes (LOPES, 2011 [2017]), foi possível identificar que das 39 cantigas profanas de Afonso X 
que até nós chegaram, seis delas são escárnio e maldizer dedicadas às mulheres (ALFONSO X, 2010).

Das seis cantigas, quatro são sátiras ao grupo profissional das soldadeiras. Nota-se tais cantigas escarnecem suas características morais, relacionadas, sobretudo, às suas atividades sexuais. No que diz respeito a esse grupo profissional bastante recorrente no cancioneiro satírico galego-português, vê-se que são um dos alvos prediletos da sátira galego-portuguesa. De acordo com Aida Fernanda Dias, essas mulheres, frequentemente apontadas como prostitutas, faziam parte da tríade que dava vida ao cenário trovadoresco, no qual trabalhavam dançando e cantando ou trocando instrumentos juntamente com os trovadores e jograis e recebiam essa alcunha, pois obtinham solda pelo trabalho prestado, sendo consideradas "mulheres a soldo" (DIAS, 1998, p. 103). Várias delas ficaram famosas na literatura galego-portuguesa, como Maria Pérez, a Balteira, sobre a qual compôs Afonso X duas cantigas: "[Maria Pérez vi muit'assanhada,]" (B 471) e "Joan Rodriguiz foi esmar a Balteira" (B 481, V 64), ambas de sentido obsceno e alusivas à sua luxúria. Ademais, o trovador compôs sobre outra soldadeira, Domingas Eanes, em "Domingas Eanes ouve sa baralha" (B 495, V 78), uma cantiga igualmente obscena e desmoralizante; e também a uma dessas profissionais cujo nome não é especificado, em "Fui eu poer a mão noutro di-". (B 484, V 67).

Além das cantigas dirigidas às soldadeiras, o Sábio produziu também duas cantigas que representam a feiura física feminina: uma dirigida a Sancha Anes, uma velha senhora, "Achei Sancha Anes encavalgada" (B 458) e outra a nenhuma mulher específica e sim a qualquer donzela fea, em "Non quer eu donzela fea" (B 476). Nessas canções, o trovador utiliza metáforas que reduzem a mulher a um plano animalesco e objetificante.

Dentre as seis cantigas, foram escolhidas três para análise: uma alusiva à feiura física, uma alusiva à feiura moral e outra que conjuga ambas as descrições.

Como claro exemplo da sátira afonsina à feiura moral, cito a cantiga "Joam Rodriguiz foi esmar a Balteira” (B 481; V 64) (ALFONSO X, 2010, p. 196):
Joam Rodriguiz foi esmar a Balteira sa midida, per que colha sa madeira; e diss'e[le]: - Se ben queredes fazer, de tal midid'a a devedes colher [assi] e non meor, per nulha maneira.
E disse: - Esta é a madeira certeira, e, de mais, nona dei eu a vós si[n]lheira; 
e pois que s'em compasso á de meter, atan longa deve toda [a] ser, [que vaa] per antr'as pernas da 'scaleira.

A Maior Moniz dei já outra tamanha, e foi-a ela colher logo sem sanha; e Mari'Aires feze-o logo outro tal, e Alvela, que andou em Portugal; e já $i$ as colherom [e]na montanha.

E diss': - Esta é a midida d'Espanha, ca nom de Lombardia nem d'Alamanha; e porque é grossa, nom vos seja mal, ca delgada para gata rem nom val; e desto mui mais sei eu [i] ca boudanha.

Nela, o trovador compõe a respeito de um homem de nome Joam Rodriguiz que calcula e sugere à Maria Balteira a "madeira" que esta deve utilizar na construção de uma casa, recomendando-lhe o "tamanho" e a "grossura" que a peça deve ter, além de relatar experiências anteriores com outras interessadas, Maior Moniz, Mari'Aires e Alvela. Joam Rodriguiz diz à Balteira que ela deve escolher a madeira exatamente do tamanho que ele indica ("de tal midida a devedes colher/ [assi] e não meor, per nulha maneira") e a "madeira" deve ser colocada compassadamente entre as "pernas" da escaleira, um ângulo formado pela madeira no telhado (LOPES, 2011 [2017]): “e pois que s'em compasso há de meter, /atam longa deve toda [de] ser/ [que vaa] per antr'as pernas da 'scaleira". Por trás da situação cotidiana de compra ou aquisição de madeira para construção, a leitura da composição aponta o duplo sentido na palavra "madeira" que claramente faz alusão ao órgão sexual masculino. Lapa interpreta assim a cantiga: "um tal Joan Rodriguiz, de sexo avantajado, foi tirar a medida à casa da Balteira, para que sua 'madeira' nela pudesse entrar"' (LAPA, 1995, p. 26). A interpretação do sentido sexual aqui pode dar margem à leitura da feiura moral da mulher, com base no fato de a Balteira ser uma soldadeira - nas cantigas satíricas, em geral, sinônimo de prostituta ou lasciva - e, por isso, faria uso da "madeira" de Joan Rodriguiz. Assim, o trovador compõe uma cantiga que, apesar de humorada, expõe as atividades sexuais da soldadeira e reconhece-se, nessa poesia, a sátira incisiva à feiura moral dessa mulher.

Como exemplo de feiura física menciona-se a famigerada cantiga "Nom quer eu donzela fea” (B 476) (ALFONSO X, 2010, p. 165):

Non quer'eu donzela fea que [ant'] a mia porta pea. 
Non quer'eu donzela fea e negra come carvon, que ant'a mia porta pea nem faça come sison.

Non quer'eu [donzela fea que ant'a mia porta pea].

Non quer'eu donzela fea e velosa come can, que ant'a mia porta pea nen faça come alerman

Non quer'eu donzela fea que ant' a mia porta pea.

Non quer'eu donzela fea que há brancos os cabelos que ant' a mia porta pea nen faça come camelos.

Non quer'eu donzela fea que ant' a mia porta pea.

Non quer'eu donzela fea, veelha de má[a] coor que ant' a mia porta pea nen [me] faça i peior.

Non quer'eu donzela fea que ant' a mia porta pea.

Nesta, o rei satiriza uma "donzela em apuros digestivos por meio de referências escatológicas, como o verbo peer (peidar)" (LOPES, 2011 [2017]). Na cantiga, há metáforas botânicas e zoológicas ("Non quer'eu donzela fea/ e velosa come can/ que ant'a mia porta pea/ nem faça come alermã”), nas quais o trovador diz que não deseja uma donzela feia, peluda como cão e fétida como a arruda silvestre. Além disso, a composição escarnece indiretamente as velhas: "Non quer'eu donzela fea/ que há brancos os cabelos" e "Non quer'eu donzela fea, / veelha de má[a] coor", com a afirmação de que o compositor não quer uma donzela de cabelos brancos e velha. Essas comparações colocam a mulher em um plano puramente animal, e também tratam de um "tema tradicional na sátira galegoportuguesa, a burla às velhas" (PAREDES, 2010, p. 166). Nessa composição, consideramos a feiura física da(s) visada(s), pela exposição clara dos defeitos corpóreos, e também a feiura moral, já que é uma mulher capaz de "peidar-se” à frente da porta do trovador. 


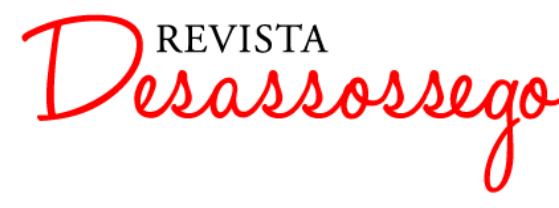

DESASSOSSEGO 17 | JUN/2017 | ISSN 2175-3180

DOI: http://dx.doi.org/10.11606/issn.2175-3180.v9i17p128-143

Outra cantiga do rei Afonso X que satiriza a mulher, desta vez pela feiura física e também moral, é a cantiga “Achei Sancha Anes encavalgada” (B 458) (ALFONSO X, 2010, p. 86):

$$
\begin{aligned}
& \text { Achei Sancha Anes encavalgada, } \\
& \text { e dix'eu por ela cousa guisada, } \\
& \text { ca nunca vi dona peior talhada, } \\
& \text { e quige jurar que era mostea; } \\
& \text { vi-a cavalgar per ũa aldeia } \\
& \text { e quige jurar que era mostea. }
\end{aligned}
$$

Vi-a cavalgar com um seu scudeiro, e non ia milhor un cavaleiro.

Santiaguei-m'e disse: - Gran foi o palheiro

onde carregaron tan gran mostea;

vi-a cavalgar per ũa aldeia

e quige jurar que era mostea.

Vi-a cavalgar indo pela rua, mui bem vistida em cima da mua; dix'eu: - Ai, velha fududancua, que me semelhades ora mostea!

Vi-a cavalgar per ũa aldeia e quige jurar que era mostea.

$\mathrm{Na}$ composição, o trovador escarnece uma velha senhora cavalgando pelas ruas de uma aldeia. Compara-a a uma mostea, um saco de palha, devido às suas formas avantajadas ("peior talhada", "mostea") ou a seu excesso de roupas ("mui bem vistida"). De acordo com Paredes, é uma cantiga que cria uma caricatura grotesca de Sancha Anes, ridicularizando seu aspecto físico e sua compostura (PAREDES, 2010, p. 87). Numa sátira explícita, o trovador zomba da feiura da mulher, afirma que nunca viu uma dona mais mal feita ("ca nunca vi dona peior talhada"); jura que ela era um saco de palha ("quige jurar que era mostea"), e a insulta, com um termo obsceno, "fududancua" ("e dix'eu: - Ai, velha fududancua, que me semelhades ora mostea!"), expressando o seu "desprezo por aquele espetáculo de gordura balofa e ambulante" (LAPA, 1995, p. 39). A sátira aqui é clara e apresenta várias expressões de insulto à mulher: "dona peior talhada", "mostea", "velha". Sendo assim, a sátira à feiura física de Sancha Anes se concretiza pela descrição da ridícula cena de seu passeio a cavalo pela aldeia. Entretanto, essa descrição parece servir, sobretudo, à evidência de sua conduta imoral: trata-se de uma mulher que pratica a sodomia ("fududancua"), completamente repugnada na Idade Média. Por conseguinte, o objeto de 
chacota nessa cantiga, ainda que aponte uma evidente feiura física, tem em vista, na verdade, a feiura moral.

\section{Considerações finais}

Com este estudo identificou-se que a sátira afonsina às mulheres era baseada em fundamentos misóginos presentes na sociedade medieval. Com base nas três composições analisadas, confirma-se que as mulheres eram satirizadas por Afonso X - e igualmente por outros trovadores galego-portugueses - por peculiaridades relativas ao que era considerado feio, como a velhice, a vestimenta e o excesso de peso, ou ao que era tido como imoral, como a lascívia e o desasseio. Sendo ele rei e trovador, ao compor cantigas que fazem rir das mulheres de aparência e comportamento inapropriados, criava ou mantinha um padrão de conduta feminina a ser perpetuado, sob pena de, desobedecido o padrão, tornarem-se as mulheres da corte alvos das impiedosas sátiras.

Ainda que o louvor à dama estabelecido pelo amor cortês suscite a ideia de que as mulheres detinham certo prestígio social no período trovadoresco, a partir da leitura da sátira afonsina contra o gênero pudemos constatar que o antifeminismo, que cingia o imaginário medieval, estava patente nessa poética. Sendo assim, considera-se que a literatura satírica galego-portuguesa contribuía para o exercício da dominação, seja do homem sobre a mulher ou do trovador sobre as soldadeiras e, especificamente no caso de Afonso X, do rei sobre a corte. Nessa perspectiva, as cantigas afonsinas ultrapassam a dimensão literária e lúdica e podem ser entendidas como uma representação de poder, por meio da crítica à feiura feminina.

\section{Referências}

A POÉTICA galego-portuguesa. Tradução de Yara Frateschi Vieira. REEL - Revista Eletrônica de Estudos Literários, Vitória, ano 1, n. 1, 2005. Disponível em: <http://periodicos.ufes.br/ reel/article/view/3270>. Acesso em: 13 dez. 2014.

ALFONSO X. El cancionero profano de Alfonso X el Sabio. Edición de Juan Paredes. Roma: Japadre/L'Aquila, 2010.

CAPELÃO, André. Tratado do amor cortês. Tradução de Claude Buridante. São Paulo: Martins Fontes, 2000. 
CARLA CASAGRANDE. "A mulher sob custódia. Tradução de Egito Gonçalves”. In: KLAPISCH-ZUBER, Christiane (Dir.). História das mulheres no Ocidente: Idade Média. Tradução de Ana Rosa Ramalho et al. Porto: Afrontamento, 1993. v. 2. p. 99-141.

CORRAL DÍAZ, Esther. As mulheres nas cantigas medievais. 2. ed. Sada: Castro, 1996.

DALARUN, Jacques. "Olhares de clérigos". In: KLAPISCH-ZUBER, Christiane (Dir.). História das mulheres no Ocidente: Idade Média. Tradução de Ana Rosa Ramalho et al. Porto: Afrontamento, 1993. v. 2. p. 29-64.

DIAS, Aida Fernanda. História crítica da Literatura Portuguesa: Idade Média. Lisboa: Verbo, 1998. v. I.

DUBY, Georges. "O modelo cortês. Tradução de Egito Gonçalves”. In: KLAPISCHZUBER, Christiane (Dir.). História das mulheres no Ocidente: Idade Média. Tradução de Ana Rosa Ramalho et al. Porto: Afrontamento, 1993. v. 2. p. 143-183.

ECO, Umberto. História da beleza. Tradução de Eliana Aguiar. São Paulo: Record, 2004.

ECO, Umberto. História da feiura. Tradução de Eliana Aguiar. São Paulo: Record, 2007.

FONSECA, Pedro Carlos Louzada. "Misoginia e retórica teologizadora da aparência feminina na Idade Média: o depoimento ascético do De cultu feminarum, de Tertuliano”. Mirabilia, Espanha, n. 17, p. 442- 466, jul./dez. 2013a. Disponível em: http://www.revistamirabilia.com/sites/default/files/pdfs/2013 02 19.pdf. Acesso em: 16 dez. 2014

FRUGONI, Chiara. "A mulher nas imagens, a mulher imaginada". Tradução de Egito Gonçalves. In: KLAPISCH-ZUBER, Christiane (Dir.). História das mulheres no Ocidente: Idade Média. Tradução de Ana Rosa Ramalho et al. Porto: Afrontamento, 1993. v. 2. p. 461-511.

LANCIANI, Giulia; TAVANI, Giuseppe (Org.). Dicionário da literatura medieval galega e portuguesa. Tradução de José Colaço Barreiros e Artur Guerra. Lisboa: Caminho, 1992.

LAPA, Manuel Rodrigues (Ed.). Cantigas d'escarnho e de mal dizer dos cancioneiros medievais galegoportugueses. Lisboa: Sá da Costa, 1995.

LE GOFF, Jacques. “O riso na Idade Média”. In. In: BREMMER, Jan; ROODENBURG, Herman (Ed.). Uma História Cultural do Humor. Rio de Janeiro:Record, 2000.

LOPES, Graça Videira. A sátira nos cancioneiros medievais galego-portugueses. 2. ed. Lisboa: Estampa, 1998. 
LOPES, Graça Videira; FERREIRA, Manuel Pedro et al. Cantigas medievais galego-portuguesas [base de dados online]. Lisboa: Instituto de Estudos Medievais, 2011 [2017]. Disponível em: <http://cantigas.fcsh.unl.pt>. Acesso em: 28 abr. 2017.

MONTOYA MARTÍNEZ, Jesús. "Caracter lúdico de la literatura medieval (A propósito del 'jugar de palabra'. Partida Segunda, tit. IX, ley XXIX)”. In: CASTILLO, C. Argente del et al. (Rec.). Homenaje al Profesor Antonio Gallego Morell. Granada: Universidad de Granada, 1989. p. 413-442.

PAREDES, Juan. "Introducción”. In: ALFONSO X. El cancionero profano de Alfonso X el Sabio. Edición de Juan Paredes. Roma: Japadre/L’Aquila, 2010. p. 35-72.

PROPP, Vladimir. Comicidade e riso. Tradução de Aurora Fornoni Bernardini e Homero Freitas de Andrade. São Paulo: Ática, 1992.

TUDELA Y VELASCO, Maria Isabel Perez de. "La mujer castellano-leonesa del pleno medievo. Perfiles literarios, estatuto jurídico y situación económica”. In: GRAINO, Cristina Seguro (Ed.). Las mujeres medievales y su âmbito jurídico. Madrid: Seminario de Estudios de la Mujer, 1983. p. 59-77.

VIEIRA, Yara Frateschi. "Retrato medieval de mulher: a bailarina com pés de porco". Revista de Estudos Portugueses e Africanos, Campinas, n. 1, p. 95-110, 1983. 